Available online at: http://ejournal-balitbang.kkp.go.id/index.php/iaj

\title{
CHARACTERISTICS OF VIRAL PROTEIN, VP-15, OF WHITESPOT SYNDROME VIRUS ISOLATED FROM INFECTED TIGER SHRIMP Penaeus monodon (Fabricius, 1798)
}

\author{
Andi Parenrengi*\#, Alimuddin**), and Andi Tenriulo*) \\ *) Research Institute for Coastal Aquaculture and Fisheries Extension \\ **) Bogor Agricultural University
}

(Received 22 September 2017; Final revised 18 October 2017; Accepted 18 October 2017)

\begin{abstract}
White spot syndrome virus (WSSV) has caused mass mortality on tiger shrimp (Penaeus monodon) culture and adversely affects prawn industry worldwide including Indonesia. It is well known that the protein structure of WSSV plays an important role in the virus infection and morphogenesis process. A viral protein structure called VP-15 is located in the nucleocapsid of virion virus. The protein structure involves in the life cycle of WSSV in host cells. A gene encoding VP-15 could be involved in constructing the RNA interference (RNAi), so it is needed to isolate and characterize for RNAi technology purpose. The study was aimed to isolate and characterize the VP-15 from the infected WSSV tiger shrimp. The characterization of VP-15 was undertaken through assessment of nucleotide sequence, amino acid deduction, alignment nucleotide/protein searches using Genetyx and BLAST program, and dendrogram construction analysis. The results showed that VP-15 was successfully isolated in form of ORFDNA with a fragment size of $243 \mathrm{bp}$. The phylogenetic tree analysis revealed three clusters corresponding to the time (year) of isolates collection. The VP-15 consisted of 80 amino acids, two start codons (ATG), one stop codon (TAA), and one Kozak context (AAAATGG). Hydrophilic amino acid was the highest composition $(44.2 \%$, followed by neutral $(31.2 \%)$ and hydrophobic $(24.6 \%)$ amino acid groups. The VP-15 was rich in amino acid of lysine $(21.3 \%$, arginine $(22.9 \%$ and serine $(24.6 \%)$. The successful isolation of VP-15 is a very important step in providing a basic yet suitable material in constructing the dsRNA vaccine to control shrimp diseases in aquaculture.
\end{abstract}

\section{KEYWORDS: $\quad$ tiger shrimp; WSSV; VP-15 gene; isolation; characterization}

\section{INTRODUCTION}

Tiger shrimp Penaeus monodon (Fabricius, 1798) is an indigenous crustacean species to Indonesia and widely popular shrimp species in brackishwater pond culture. Since 1990, tiger shrimp culture has been affected by problems of degrading culture environment and viral disease outbreaks. At least 20 viruses causing shrimp diseases have been reported by Zhang et al. (2004). White spot syndrome virus (WSSV) is one of the major virulent viruses infecting shrimp in pond culture and hatchery. WSSV virion consists of an enveloped nucleocapsid containing a circular double-stranded DNA genome (Van-Hulten et al., 2002). The WSSV protein structure or viral protein VP-28

\footnotetext{
\# Correspondence: Research Institute for Coastal Aquaculture and Fisheries Extension. Jl. Makmur Dg. Sitakka No. 129, Maros, South Sulawesi 90512, Indonesia.

Phone: + 62411371544

E-mail: andi_parenrengi@ hotmail.com
}

and VP-19 are located in the nucleocapsid envelope whereas VP-26 and VP-24 are located within the nucleocapsid. Recently, the smallest nucleocapsid protein was discovered in WSSV and called VP-15. It is thought to be involved in WSSV genomic packaging based on its DNA binding and condensing abilities (Ying, 2004); Tsai et al., 2006; Sangsuriya et al., 2011).

The application of biotechnology to increase fish/ shrimp resistance against pathogens is one of the alternatives to control disease occurrences and outbreaks in aquaculture. For example, the application of penaeidin showed a significant disease resistance by Litopenaeus vannamei (Destoumieux et al., 1997), and coated TSV protein (taura syndrome virus) increased L. vannamei resistance about 39\% to TSV diseases (Lu \& Sun, 2005). Besides that, a genetic engineering through RNA interference (RNAi) technology can also be considered as a potential mechanism in improving fish diseases resistance. 
RNAi is a technology used to inhibit the expression of virulent genes of a pathogen which subsequently prevent the virus infection to fish/shrimp. The immune inductions of shrimp through vaccination techniques have been successfully conducted using protein recombinant WSSV on P. chinensis (Kim et al., 2004) and antiviral dsRNA on L. vannamei (Robalino et al., 2004), and to stimulate the gonad maturation in tiger shrimp (Wulandari, 2010; Treerattrakool et al., 2013), to protect against infectious virus on L. vannamei (Loy et al., 2012; Solis-Lucero et al., 2016),P. japonicas (Namikoshi et al., 2004), and P. monodon (Witteveldt et al., 2004). The application of antisense RNA in protecting $L$. vannamei from WSSV infection was also reported by Akhila et al. (2015). The dsRNA from VP-28 was reported to be useful in protecting Macrobrachium rosenbergii from WSSV (Jariyapong et al., 2015). Several studies also demonstrated the success of VP-19 isolation from the WSSV infected shrimp (Alim et al., 2011; Hidayani et al., 2016). Currently, the RNAi technology to produce dsRNA vaccine for VP-15 has not yet developed. Therefore, the first development stage is the isolation of gene target to provide agene material to construct the RNAi technology. The study was aimed to isolate and characterize the gene encoding the viral protein VP-15 from the tiger shrimp infected by WSSV pathogen to provide the basic material in constructing the RNAi technology.

\section{MATERIALS AND METHODS}

\section{Shrimp Samples}

The samples of tiger shrimp were collected from brackish water ponds in Takalar Regency with sizes ranged between 7-15 g. Nine samples from positive WSSV-infected tiger shrimp were selected consisting of three samples from the disease outbreaks in 2012, one sample in 2013, and five samples in 2014. Approximately $30 \mathrm{mg}$ of shrimp tissue from each sample was preserved in ethanol $90 \%$ solution prior to transporting to the biotechnology laboratory of Research Institute for Coastal Aquaculture (RICA) in Maros. In order to confirm the infection of WSSV in the samples, viral detection was performed using the commercial kit IQ-2000.

\section{Genomic DNA Extraction}

DNA extraction was performed using CTAB (cetyl trimethylammonium bromide) method. Approximately 0.3-0.6 mg of each sample was placed, mixed, and digested using the plastic pastel in a $1.5 \mathrm{~mL}$ microtube. The microtubes were added with $C T A B$ solution and then vortexed before incubation at $75^{\circ} \mathrm{C}$ for 5 minutes. After drying at room temperature, the tubes were added with $0.7 \mathrm{~mL}$ and then vortexed for 20 seconds and centrifuged at 12,000 rpm for 5 minutes. The supernatant from each tube was collected and added with $100 \mathrm{~mL} \mathrm{CTAB}$ and $900 \mathrm{~mL} \mathrm{ddH_{2 }} \mathrm{O}$. The mixed solutions were slightly vortexed and then incubated at $75^{\circ} \mathrm{C}$ for 5 minutes and then allowed cool down to room temperature. The samples were recentrifuged at $12,000 \mathrm{rpm}$ for 10 minutes. The supernatants were discarded and the remaining pelleted materials were mixed with $150 \mathrm{~mL}$ dissolve solution. After centrifugation at 12,000 rpm for 5 minutes, each supernatant was transferred to a new microtube filed with $300 \mathrm{~mL}$ cold ethanol 95\% The samples were centrifuged at $12.000 \mathrm{rpm}$ for 5 minutes and the ethanol was discarded. The pellet was mixed with $300 \mu$ L ethanol $70 \%$ and then centrifuged at $12.000 \mathrm{rpm}$ for 5 minutes. The ethanol was discarded and the pellet was allowed to dry at room temperature for 2 hours and finally added with $100 \mathrm{~mL}$ TE buffer.

\section{Measurement of Concentration and Purity of Genomic DNA}

The concentration and purity of the genomic DNA were measured using the GeneQuant at wavelengths of 260 and $280 \mathrm{~nm}$. The quality of DNA genomes was also confirmed by electrophoresis at $0.5 \%$ agarose gel. The concentration and purity were calculated based on the formula of Linacero et al. (1998).

\section{Detection of White Spot Diseases}

The infection of white spot disease was molecularly detected using Polymerase Chain Reaction (PCR) technique in two steps. First, PCR was performed following the programmed steps: 5 cycles for denaturation at $94^{\circ} \mathrm{C}$ for 30 seconds; annealing at $62^{\circ} \mathrm{C}$ for 30 seconds; extension at $72^{\circ} \mathrm{C}$ for 30 seconds and then followed by 15 cycles of denaturation at 94 으 for 15 second; annealing $62^{\circ} \mathrm{C}$ for 15 seconds; and extension at $72^{\circ} \mathrm{C}$ for 20 seconds. The nested PCR was conducted following the steps as follows: 25 cycles of denaturation at $94^{\circ} \mathrm{C}$ for 20 second; annealing $62^{\circ} \mathrm{C}$ for 30 seconds; extension at $72^{\circ} \mathrm{C}$ for 30 seconds; and following by denaturation at $72^{\circ} \mathrm{C}$ for 30 second; and hold at $20^{\circ} \mathrm{C}$ for 30 seconds. PCR products were separated in $2 \%$ gel electrophoresis and observed under UV-transilluminator.

\section{Isolation and Nucleotide Sequence of VP-15 WSSV}

VP-15 was isolated from the genomic DNA of positively infected shrimp. Only the samples that have a high-level infection were used in the PCR process. Isolation was done following the method suggested 
by Sarathi et al (2010) using forward primer VP-15 F: 5'-cgcggatccgatgacaaaataccccgagaac-3 and reverse primer VP-15 R: 5- ccggaattcttaacgccttgacttgcggg-3'. DNA amplification was performed in GeneAmp PCR System 2700. PureTaq RTG PCR beads kit was used as the PCR reaction and mixed with primer for each 1 $\mu \mathrm{L}(50 \mathrm{\rho mol} / \mathrm{mL})$. The PCR process was carried out at pre-denaturation temperatures of $94^{\circ} \mathrm{C}$ for 3 minutes; for 35 cycles (denaturation at $94^{\circ} \mathrm{C}$ for 1 min, annealing at a temperature of $57^{\circ} \mathrm{C}$ for 45 seconds, extension at a temperature of $72^{\circ} \mathrm{C}$ for $1 \mathrm{~min}$ ); and a final extension at a temperature of $72^{\circ} \mathrm{C}$ for 5 minutes. The PCR result was electrophorezed using $2 \%$ agarose gel and documented by Gel Documentation System. The PCR products were then sent to the laboratory First Base Singapore for nucleotide sequencing.

\section{Data Analysis}

VP-15 nucleotide sequencing was done using the Genetyx version 7 to obtain a consensus of readings forward and reverse, as well as amino acid deduction. To determine the similarity of nucleotide sequences, the VP-15 sequences were aligned with the sequences that already exist in the GenBank using the BLAST-N (Basic Local Alignment Search Tool-Nucleotide). The results of data analysis were descriptively presented.

\section{RESULTS AND DISCUSSION}

\section{Purity and Concentration of Genomic DNA}

The level of purity of genomic DNA from tiger shrimp was in the range of 1.80 to 1.84 (average value of $1.84 \pm 0.04$ ). The value indicated that the DNA purity level was sufficiently enough for the amplification purposes. Linacero et al. (1998) stated that the purity level of the DNA should be in the range of 1.8 to 2.0, for DNA amplification. The concentration of genomic DNA obtained was in the range of 25.95$43.80 \mu \mathrm{g} / \mathrm{mL}$ (average value of $36.58 \pm 9.40 \mu \mathrm{g} / \mathrm{mL}$ ).

\section{Detection of White Spot Disease}

The disease detection has shown that all samples indicated a positive contamination of WSSV genome by moderate ( 5 and 7$)$ to high $(1,2,3,4$, and 6 ) infection (Figure 1). This Figure was just a representative work of detection of white spot diseases from the year 2012 isolates. In this case, among the seven samples of tiger shrimp, three samples with high levels of infections $(3,4$, and 6$)$ were selected for isolation of VP-15 WSSV. It was assumed that the more severe virus infection, the higher the concentration of viral DNA integrated with the genomic DNA in the tiger shrimp. However, the white spot diseases infection could be also detected through the PCR technique using specific primers for WSSV or real-time PCR.

\section{Isolation of VP-15 WSSV}

VP-15 gene has been isolated from WSSV in genomic DNA of infected tiger shrimp. The electrophoresis resulted in a single DNA fragment at the position between 200-300 bp (Figure 2). Sarathi et al., (2010) reported that the isolation of genes VP15 from black tiger shrimp in India was confirmed in a position of DNA fragments of approximately 245 bp.

Figure 2 suggested a single clear band of an appropriate target gene of VP-15. However, the intensity of each band varied among the samples. Line 1 showed stronger band compared to the other lines, which was supposed to be an indicator of the higher concentration of virus DNA.

\section{Nucleotide Sequence Analysis of VP-15 WSSV}

The VP-15 genes isolated in 2012, 2013, and 2014 samples showed a relatively high homology of nucleotide. However, VP-15 isolated from 2013 samples showed some differences compared to other isolates (Figure3A). Based on the UPGMA (Unweighted Pair Group Method of Arithmetic) analysis, three clusters according to the time (year) of sample collection (Figure 3B) were identified. The isolates collected in 2014 showed identical nucleotide sequence, except the $M 7$ isolate showing a closer relationship to the isolates of 2012. The isolate of 2013 seemed to be clustered within itself and relatively separated to the isolates of 2012 and 2014. The present study revealed identical nucleotides of VP-15 between isolates, for instance: 4 samples from 2014 isolates (samples of M2, M 5, M8, and M9) and 2 samples from 2012 and 2014 isolates (samples of 06 and M7). The identical nucleotides of VP-15 were confirmed by the nucleotide alignment analysis. Figure $3 \mathrm{~A}$ showed the same color indicating the same nucleotide and the Figure $3 \mathrm{~B}$ also showed the dendrogram of the phylogenetic tree in one cluster for one identical nucleotide by the value of 0.000 . However, the phylogenetic tree showed close relationship for each VP-15 in the value of 0.000-0.0266.

The different nucleotides were only observed in 1-5 upstream nucleotides and the last two nucleotides (Figure 3A). This indicated that the white spot diseases outbreak in 2012, 2013, and 2014 was suspected from a similar virus which infected the tiger shrimp 


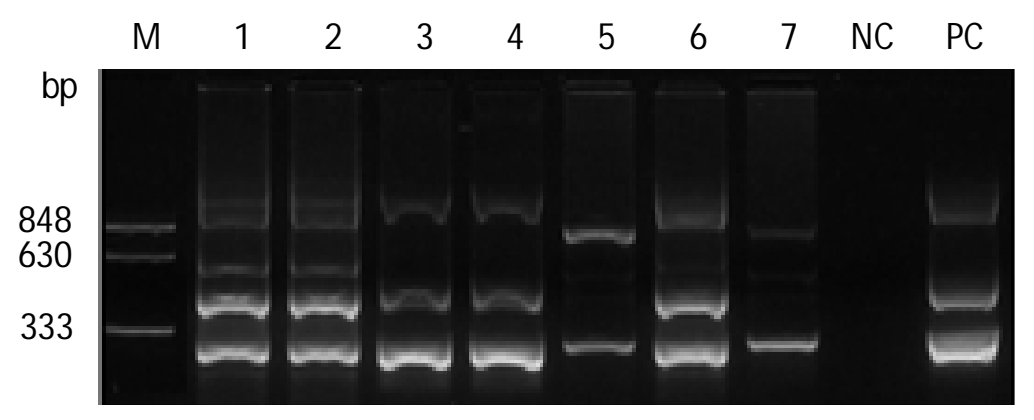

Figure 1. The electrophoresis of white spot syndrome virus detection in tiger shrimp on agarose gel $(b p=$ base pair; $M=$ Marker DNA; $1-7=$ tiger shrimp samples; $N C=$ negative control; and $\mathrm{PC}=$ positive control).

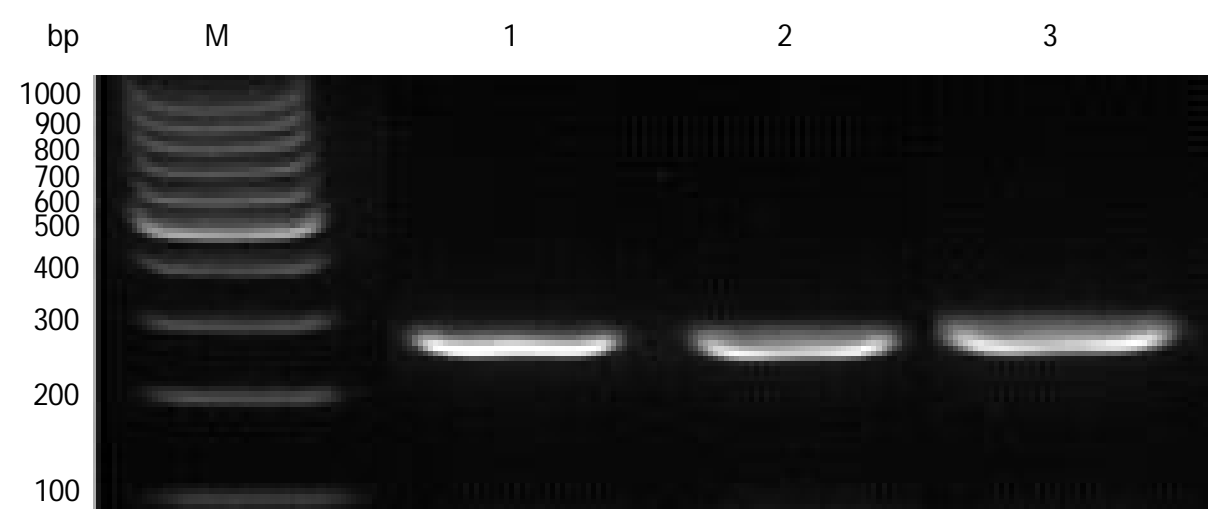

Figure 2. Gel electrophoresis of a gene encoding VP-15 WSSV from infected tiger shrimp ( $b p=$ base pair; $M=$ marker DNA; and 1-3= representative samples of tiger shrimp).

in Takalar regency. Not only intra-isolate nucleotide analysis but inter-isolate nucleotide analysis also showed the high nucleotide identity (up to $99 \%$ for the worldwide isolates of VP-15 gene deposited in GenBank. Based on obtained nucleotide homology using BLAST-N program, fifteen samples of WSSV isolates had the highest identity $(96-99 \%)$ in query coverage ranged from $73-100 \%$ with the isolates of this present study were listed in Table 1.

The local alignment showed that the genes encoding VP-15 isolated from Indonesia (Takalar regency) had a similarity of nucleotide sequence ranged from $96 \%$ to $99 \%$ with the VP-15 WSSV isolated from other countries in the world (Table 1). The present study suggests that the WSSV infecting the tiger shrimp in Indonesia is relatively close to WSSV infecting shrimp in other counties in Asia and Latin America. A similar finding of VP-19 nucleotide sequence from Indonesian isolates also reported a high similarity with that of Mexican isolates (Hidayani et al., 2016).

\section{Transcription Factor and Amino Acid Deduction of VP-15 WSSV}

The Open Reading Frame (ORF) of VP-15 consisted of 80 amino acids. The partial gene encoding PV-15 including nucleotide sequence and the amino acid deduction was shown in Figure 4. The isolation of gene VP-15 from tiger shrimp in India confirmed the position of DNA fragments of about 245bp (Sarathi et al., 2010) which was relatively similar in length to that of the present study. Figure 4 also indicated two start codons located on the $11^{\text {th }}$ nucleotide and the $58^{\text {th }}$ nucleotide in the partial gene. The first ATG of this ORF was apparently not used, because this ATG was in an unfavorable Kozak context (TTCGATGA) for efficient translation initiation, whereas the second ATG was in a favorable Kozak context (AAAATGG). This was also confirmed the N-terminal sequence by indicating the valine amino acid after the second ATG (methionine). 
2012_03_VP15.gnu 2012_05_VP15.gnu 2012_06_PV15.gnu 2013 25_PV15.gpt 2014_M2_VP15.gnu 2014_M5_PV15.gnu 2014_M7_PV15.gnu 2014_M8_VP15.gnu 2014_M9_PV15.gnu

2012_03_VP15.gnu 2012_05_VP15.gnu 2012_06_PV15.gnu 2013_25_PV15.gpt 2014 M2 VP15.gnu 2014_M5_PV15.gnu 2014_M7_PV15.gnu 2014_M8_VP15.gnu 2014_M9_PV15.gnu

2012_03_VP15.gnu 2012_05_VP15.gnu 2012_06_PV15.gnu 2013_25_PV15.gpt 2014_M2_VP15.gnu 2014 M5 PV15.gnu 2014_M7_PV15.gnu 2014_M8_VP15.gnu 2014_M9_PV15.gnu

2012_03_VP15.gnu 2012_05_VP15.gnu 2012_06_PV15.gnu 2013_25_PV15.gpt 2014_M2_VP15.gnu 2014_M5_PV15.gnu 2014_M7_PV15.gnu 2014_M8_VP15.gnu 2014_M9_PV15.gnu

2012_03_VP15.gnu 2012_05_VP15.gnu 2012_06_PV15.gnu 2013_25_PV15.gpt 2014_M2_VP15.gnu 2014_M5_PV15.gnu 2014_M7_PV15.gnu 2014_M8_VP15.gnu 2014_M9_PV15.gnu

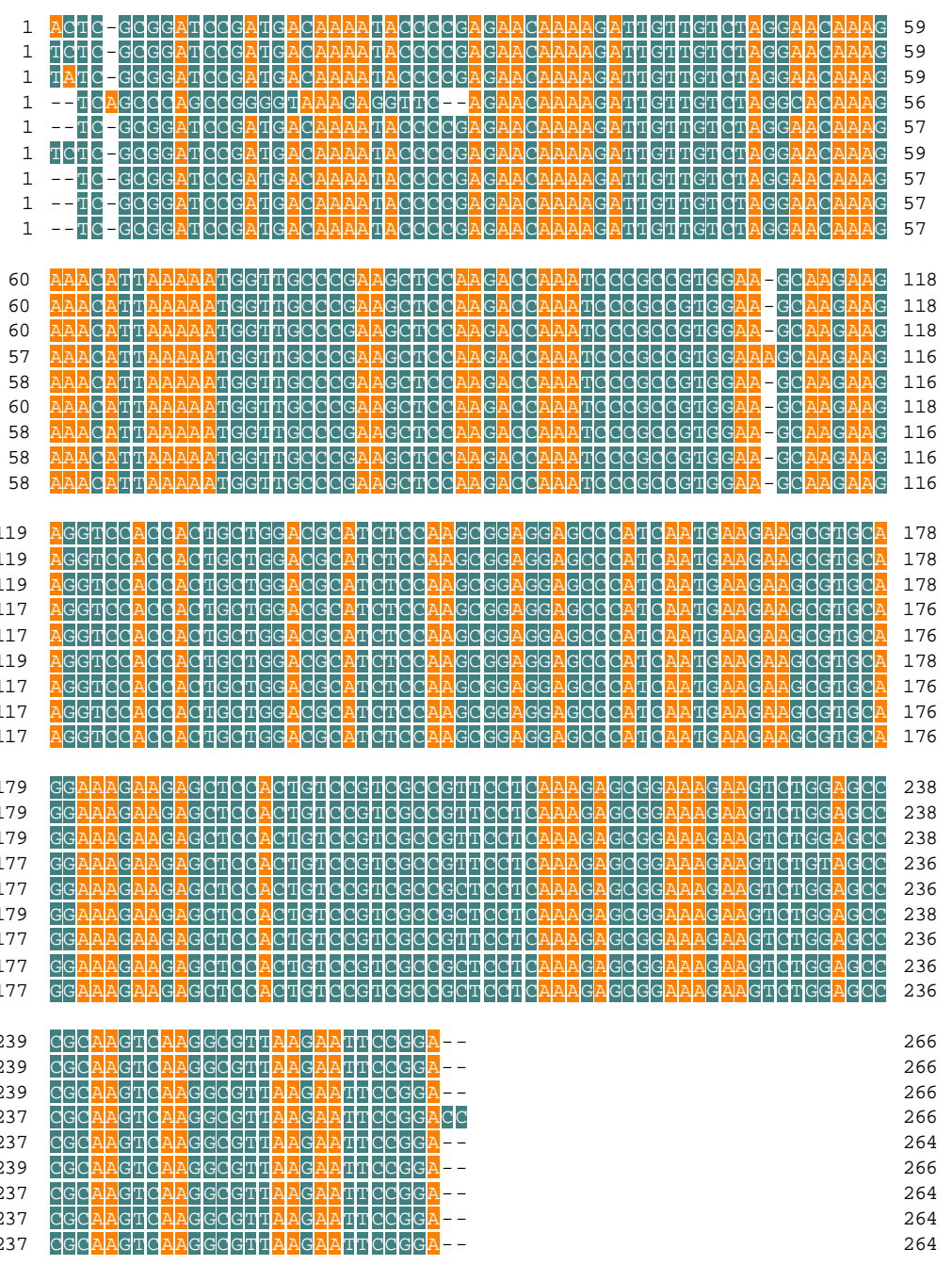

A

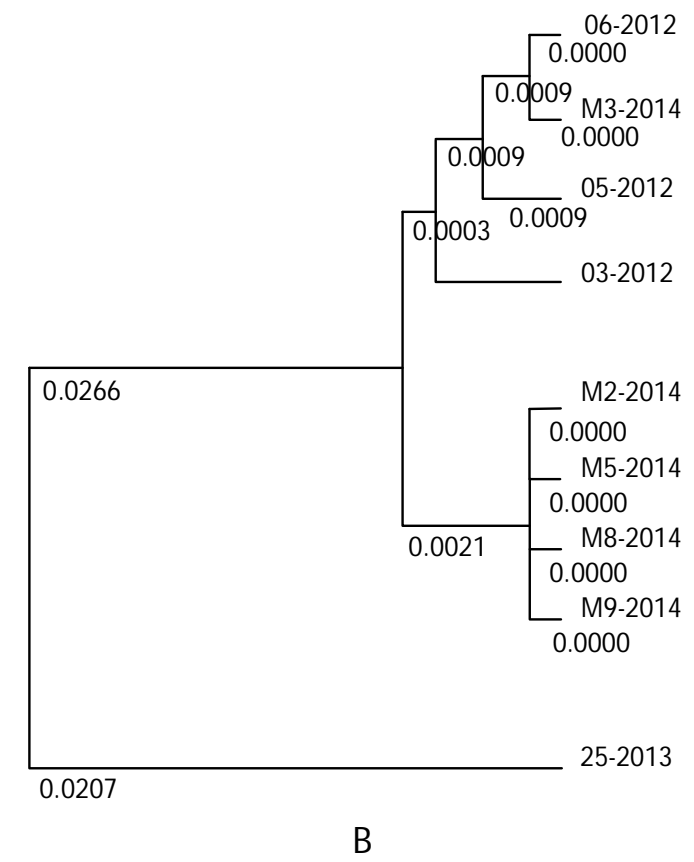

Figure 3. Nucleotide sequence alignment (A) and phylogenetic tree (B) of gene encoding VP-15 WSSV isolated from infected tiger shrimp collected in 2012, 2013, and 2014. 
Table 1. Similarity index of VP-15 nucleotide sequence isolated from infected tiger shrimp with the gene VP-15 deposited in the GenBank

\begin{tabular}{|c|c|c|c|c|c|}
\hline Description & $\begin{array}{l}\text { Maximal } \\
\text { score }\end{array}$ & $\begin{array}{l}\text { Total } \\
\text { score }\end{array}$ & $\begin{array}{l}\text { Query } \\
\text { coverage }\end{array}$ & $\begin{array}{l}\text { Maximal } \\
\text { identity }\end{array}$ & Accession \\
\hline WSSV strain CNO2, complete genome & 444 & 444 & $100 \%$ & $99 \%$ & KT995470.1 \\
\hline WSSV isolate EG3, complete genome & 444 & 444 & $100 \%$ & $99 \%$ & KR083866.1 \\
\hline White spot syndrome virus, complete genome & 444 & 444 & $100 \%$ & $99 \%$ & AF332093.3 \\
\hline WSSV strain K-LV1, complete genome & 444 & 444 & $100 \%$ & $99 \%$ & JX515788.1 \\
\hline Shrimp WSSV partial VP-15 gene for nucleocapsid protein & 444 & 444 & $100 \%$ & $99 \%$ & AJ937742.1 \\
\hline White spot syndrome virus, complete genome & 444 & 444 & $100 \%$ & $99 \%$ & AF369029.2 \\
\hline Shrimp WSSV, complete genome & 444 & 444 & $100 \%$ & $99 \%$ & AF440570.1 \\
\hline Shrimp WSSV from India VP-15 (VP-15) gene, complete cds & 440 & 440 & $99 \%$ & $99 \%$ & DQ681072.1 \\
\hline Shrimp WSSV isolate China 95/Dalian VP15 gene, complete cds & 435 & 435 & $100 \%$ & $99 \%$ & AY249449.1 \\
\hline Shrimp WSSV VP15 gene, complete cds & 427 & 427 & $100 \%$ & $98 \%$ & AY220743.1 \\
\hline Shrimp WSSV major structural protein VP15 gene, partial cds & 425 & 425 & $100 \%$ & $98 \%$ & DQ902654.1 \\
\hline WSSV DNA binding protein mRNA, complete cds & 405 & 405 & $91 \%$ & $99 \%$ & AF227910.1 \\
\hline Shrimp WSSV isolate China 95/Dalian unknown mRNA & 361 & 361 & $92 \%$ & $96 \%$ & AY245784.1 \\
\hline Shrimp WSSV isolate Korea 01 VP-15 gene, complete cds & 339 & 339 & $76 \%$ & $99 \%$ & AY374120.1 \\
\hline $\begin{array}{l}\text { Shrimp WSSV isolate Mexican nucleocapsid protein VP-15 gene, } \\
\text { partial cds }\end{array}$ & 324 & 324 & $73 \%$ & $99 \%$ & AY713371.1 \\
\hline
\end{tabular}

cgcggatccgatgacaaaataccccgagaacaaaagattgttgtctaggaacaaagaa

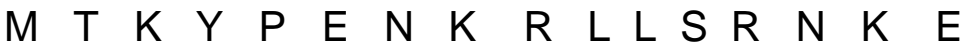

acattaaaatggttgcccgaagctccaagaccaaatcccgccgtggaagcaagaag

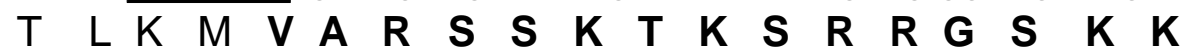
aggtccaccactgctggacgcatctccaagcggaggagcccatcaatgaagaagcgt $\begin{array}{llllllllllllllllllll}\mathbf{R} & \mathbf{S} & \mathbf{T} & \mathbf{T} & \mathbf{A} & \mathbf{G} & \mathbf{R} & \mathbf{I} & \mathbf{S} & \mathbf{K} & \mathbf{R} & \mathbf{R} & \mathbf{S} & \mathbf{P} & \mathbf{S} & M & \mathrm{~K} & \mathrm{~K} & \mathbf{R}\end{array}$

gcaggaaagaagagctccactgtccgtcgccgctcctcaaagagcggaaagaag

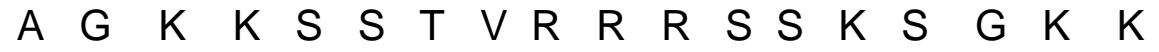

tctggagcccgcaagtcaaggcgttaagaattccgg

$S G A R K S R R$ *

Figure 4. Nucleotide sequence and amino acid deduction of VP-15 WSSV from infected tiger shrimp. Forward and reverse primers sequence were underlined nucleotide, the Kozak context was boxed, start codon was in bold nucleotides, and stop codon was in italic nucleotide, the $\mathrm{N}$-terminal sequence was in bold amino acids, nucleotide symbol (small letters) $a=$ adenine, $c=$ cytosine, $g=$ guanine, $t=$ thymine; and amino acid deduction (capital letters) $\mathrm{A}=$ alanine, $\mathrm{R}=\operatorname{arginine}, \mathrm{N}=$ asparagine $\mathrm{G}=$ glysine, $\mathrm{E}=$ glutamic acid, $\mathrm{I}=$ isoleucine, $\mathrm{K}=$ lysine, $\mathrm{M}=$ methionine, $\mathrm{P}=$ proline, $\mathrm{S}=$ serine, $T=$ threonin, $Y=$ tyrosine, and $V=$ valine. 

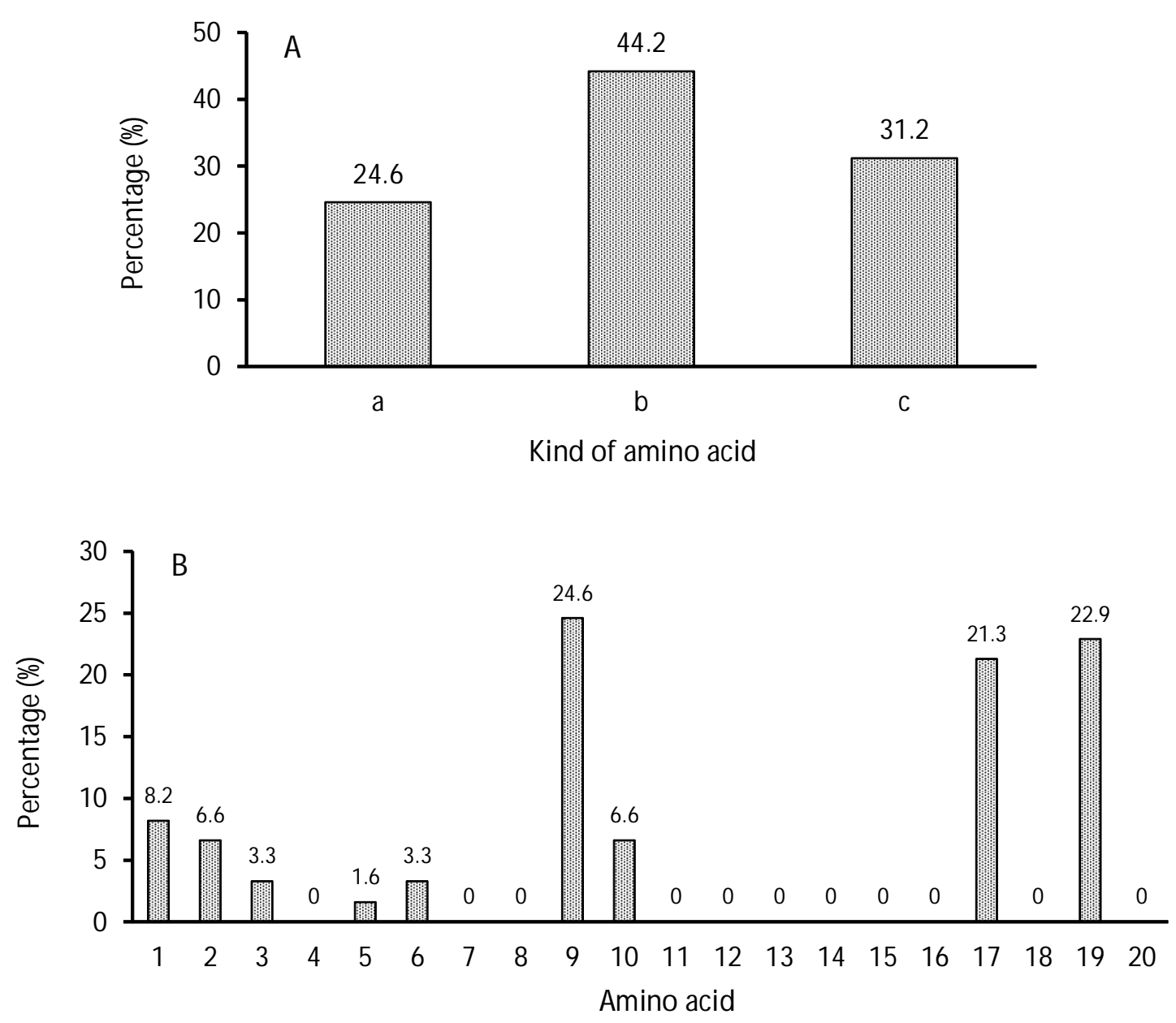

Figure 5. Amino acid composition of VP-15 WSSV isolated from infected tiger shrimp. (A) Amino acid groups of hydrophobic (a), hydrophilic (b) and neutral (c) type. (B) Amino acid of glysine (1), alanine (2), valine (3), leucine (4), isoleucine (5), methionine (6), phenylalanine (7), tryptopan (8), proline (9), serine (10), threonine (11) asparagine (12), glutamine (13), cysteine (14), aspartic acid (15), glutamic acid (16), lysine (17), histidine (18), arginine (19), and tyrosine (20).

Based on the nucleotide sequence of VP-15, the Kozak context was indicated in the surrounding of the second star codon. The Kozak context indicated the efficient eukaryotic translation initiation. VanHulten et al. (2002) reported that the Kozak context was also located at the sequence surrounding the methionine of the second star codon on the sequence of VP-19 form WSSV. The TATA-box consensus sequence was present with 254 nucleotides upstream of the ATG and a consensus polyadenylation (poly-A) signal was present with 60 nucleotides downstream of the translation stop codon of VP-19. Figure 5 showed a partial sequence of WSSV based on the reference of the gene encoding the VP-15, including its ORF sequence. However, the complete sequence of WSSV has recently been reported by Van-Hulten et al. (2002).

Marks et al. (2003) reported that a VP-15 was the only major protein structure gene with a consensus TATA-box compared to VP-19, VP-24, and VP-28, in which the earlier onset of transcription of VP-15 could be regulated by this TATA-box, as in other WSSV genes which have been shown or are likely to be expressed early in an infection (Tsai et al., 2000; Liu et al., 2001; Chen et al., 2002). Van-Hulten et al. (2002) stated that VP-15 is a very basic protein and resembles histone protein which functions as a DNA-binding protein in the WSSV nucleocapsid. The N-terminal methionine is probably removed from the nascent 
VP-15 polypeptide by N-terminal protein processing (Giglione et al., 2000) and this explains the start of VP-15 with a valine. A VP-15 encoding the $14 \pm 5 \mathrm{kDa}$ protein has been described by Wang et al. (2000) in the WSSV virion and N-terminal sequencing revealed the sequence VARGGKTKGRRG, which was similar to the VP-15 sequence described in this study.

\section{Analysis of Amino Acid Encoding VP-15 WSSV}

VP-15 amino acid deduction in this study showed an identical (100\% alignment compared to the VP-15 WSSV isolated by Van-Hulten et al. (2002). The highest percentage of the hydrophilic amino acid group was obtained in the VP-15 approximately $44.2 \%$ followed by neutral (31.2\% and hydrophobic (24.6\%) amino acid groups (Figure 5A). The composition of the amino acid was rich in lysine $(21.3 \%$, arginine $(22.9 \%$ and serine $(24.6 \%)$ (Figure 5B).

Van Hulten et al. (2002) also reported similar amino acid compositions of VP-15 isolated from WSSV. In relation to the antiviral gen from tiger shrimp, Parenrengi et al. (2009) also reported that the highest percentage of the amino acid encoding antiviral gene was serine $(10.00 \%$, while the lowest was proline and lysine $(1.76 \%$.

\section{CONCLUSION}

A gene encoding VP-15 was successfully isolated from infected tiger shrimp with fragment size at 243 bp and had a very high similarity (up to $99 \%$ with the VP-15 deposited in the GenBank. Three clusters were revealed in the present study corresponding to the time (year) of isolates collection. The VP-15 consisted of 80 amino acids, two start codons, one stop codon, and one Kozak context. The VP-15 was rich in an amino acid of lysine, arginine, and serine. The characteristics of VP-15 suggested that it could be used as a basic material in constructing the RNAi technology to control shrimp diseases in aquaculture.

\section{ACKNOWLEDGMENT}

This study was supported by the Indonesian Government through DIPA-APBN 2015. The authors gratefully thank the researchers and technicians at the Biotechnology Laboratory of RICA and Andi Ninnong Renita (Hasanuddin University) for her technical support.

\section{REFERENCES}

Akhila, D.S., Mani, M.K., Rai, P., Condon, K., Owens, L., \& Karunasagar, I. (2015). Antisense RNA mediated protection from white spot syndrome virus (WSSV) infection in Pacific white shrimp Litopenaeus vannamei. Aquaculture, 435, 306-309.

Alim, S., Wahjuningrum, D., \& Ali, M. (2011). Cloning and sequencing of VP19-encoding gene of white spot syndrome virus from Situbondo's isolate. Jurnal Akuakultur Indonesia, 10 (2), 154- 164 (in Indonesian with English abstract).

Chen, L.L., Wang, H.C., Huang, C.J., Peng, S.E., Chen, Y.G., Lin, S.J., Chen, W.Y., Dai, C.F., Yu, H.T., Wang, C.H., Lo, C.F., \& Kou, G.H. (2002). Transcriptional analysis of the DNA polymerase gene of shrimp white spot syndrome virus. Virology, 301, 136147.

Destoumieux, D., Bulet, P., Loew, D., Dorsselaer, A.V., Rodriguez, J., \& Bachere, E. (1997). Panaeidins, a new family of antimicrobial peptide isolated from the shrimp Penaeus vannamei (Decapoda). Journal of Biological Chemistry, 272(45), 28398-28496.

Hidayani, A.A., Tassakka, A.C.M.A.R., \& Parenrengi, A., (2016). Isolation and characterization of an envelope protein (VP19) of a White Spot Syndrome Virus from diseased vannamei (Litopenaeus vannamei) in Indonesia. AACL Bioflux, 9(2), 389395.

Giglione, C., Serero, A., Pierre, M., Boisson, B., \& Meinnel, T. (2000). Identification of eukaryotic peptide deformylases reveals the universality of $\mathrm{N}$-terminal protein processing mechanisms. EM BO Journal, 19, 5916-5929.

Jariyapong, P., Charoonroj Chotwiwatthanakun, C., Direkbusarakom, S., Hirono, I., Wuthisuthimethavee, S., \& Weerachatyanukul, W. (2015). Delivery of double-stranded RNA by Macrobrachium rosenbergii nodavirus-like particles to protect shrimp from white spot syndrome virus. Aquaculture, 435, 86-91.

Kim, D.K., Jang, I.K., Seo, H.C., Shin, S.O., Yang, S.Y., \& Kim, J.W. (2004). Shrimp protected from WSSV disease by treatment with egg yolk antibodies (IgY) against a truncated fusion protein derived from WSSV. Aquaculture, 237, 21-30.

Linacero, J., Rueda, \& Vazquez, A.M. (1998). Quantification of DNA. Pages 18-21, In Isaac, G., Ingram, D.S. (editors). Molecular Tools for Screening Biodiversity: Plants and Animals. Chapman and Hall. London, Weinheim, New York, Tokyo, Melbourne, Madras.

Liu, W.J., Yu, H.T., Peng, S.E., Chang, Y.S., Pien, H.W., Lin, C.J., Huang, C.J., Tsai, M.F., Huang, C.J., Wang, C.H., Lin, J.Y., Lo, C.F., \& Kou, G.H. (2001). 
Cloning, characterization, and phylogenetic analysis of a shrimp white spot syndrome virus gene that encodes a protein kinase. Virology, 289, 362-377.

Loy, J.D., Mogler, M.A., Loy, S.S., Janke, B., Kamrud, K., Scura, E.D., Harris, D.L.H., \& Bartholomay, L.C. (2012). dsRNA provides sequence-dependent protection against infectious myonecrosis virus in Litopenaeus vannamei. Journal of General Virology, 93, 880-888.

Lu, Y. \& Sun, P.S. (2005). Viral resistance in shrimp that express an antisense taura syndrome virus coat protein gene. Antiviral Research, 67,141-146.

Marks, H., Mennens, M., Just, M.V., \& Van-Hulten M.C.W. (2003). Transcriptional analysis of the white spot syndrome virus major virion protein genes. Journal of General Virology, 84, 1517-1523.

Namikoshi, A., Wu, J.L., Yamashita, T., Nishizawa, T., Nishioka, T., Arimoto, M., \& Muroga, K. (2004). Vaccination trials with Penaeus japonicas to induce resistance to white spot syndrome virus. Aquaculture, 229(1), 25-35.

Parenrengi, A., Alimuddin, Sukenda, Sumantadinata, K., \& Tenriulo, A. (2009). Characteristic of cDNA sequence encoding antiviral gene from tiger shrimp, Penaeus monodon. Jurnal Riset Akuakultur, 4, 1-13 (in Indonesian with English abstract).

Robalino, J., Browdy, C.L., Prior, S., M etz, A., Parnell, P., Gross. P., \& Warr, G. (2004). Induction of antiviral immunity by double-stranded RNA in a marine invertebrate. Journal of Virology, 78(19), 1044210448.

Sangsuriya, P., Senapin, S., Huang, W.P., Lo, C.F., \& Flegel, T.W. (2011). Co-Interactive DNA-Binding between a Novel, Immunophilin-Like Shrimp Protein and VP15 Nucleocapsid Protein of White Spot Syndrome Virus. PLOS ONE, 6(9), e25420.

Sarathi, M., Simon, M.C., Venkatesan, C., Thomas, J., Ravi, M., Madan, N., Thiyagarajan, S., \& Hameed, A.S.S. (2010). Efficacy of bacterially expressed dsRNA specific to different structural genes of white spot syndrome virus (WSSV) in the protection of shrimp from WSSV infection. Journal of Fish Diseases, 33, 603-607.

Solis-Lucero, G., M anoutcharian, K., Hernandez-Lopez, J., \& Ascencio, F. (2016). Injected phage-displayed-
VP28 vaccine reduces shrimp Litopenaeus vannamei mortality by white spot syndrome virus infection. Fish and Shellfish Immunology, 55, 401-406.

Treerattrakool, S., Chartthai, C., Phromma-in, N., Panyim, S., \& Udomkit, A. (2013). Silencing of gonad-inhibiting hormone gene expression in Penaeus monodon by feeding with GIH dsRNAenriched Artemia. Aquaculture, 404-405, 116-121.

Tsai, M.F., Lo, C.F., van Hulten, M.C.W., Tzeng, H.F., Chou, C.M., Huang, C.J., Wang, C.H., Lin, J.Y., Vlak, J.M., \& Guang-Hsiung, G.H. (2000). Transcriptional analysis of the ribonucleotide reductase genes of shrimp white spot syndrome virus. Virology, 277, 92-99.

Tsai, J.M., Wang, H.C., Leu, J.H., Wang, A.H.J., Zhuang, Y., Walker, P.J., Kou, G.H., \& Lo, C.F. (2006). Identification of the Nucleocapsid, Tegument, and Envelope Proteins of the Shrimp White Spot Syndrome Virus Virion. Journal of Virology, 80 (6), 3021-3029

Van-Hulten, M.C.W., Reijns, M., Vermeesch, A.M.G., Zandbergen, F., \& Vlak, J.M. (2002). Identification of VP19 and VP15 of white spot syndrome virus (WSSV) and glycosylation status of the WSSV major structural proteins. Journal of General Virology, 83, 257-265.

Wang, Q., Poulos, B.T., \& Lightner, D.V. (2000). Protein analysis of geographic isolates of shrimp white spot syndrome virus. Archives of Virology, 145, 263-274.

Witteveldt, J., Vlak, J.M., \& van-Hulten, M.C.W. (2004). Protection of Penaeus monodon against white spot syndrome virus using a WSSV subunit vaccine. Fish and Shellfish Immunology, 16, 571-579.

Wulandari, A.S. (2010). Construct and production gonad-inhibiting hormone dsrna of black tiger prawn (Penaeus monodon) by in vitro and in vivo technique in L4440 expression vector. Master Thesis, Bandung Institute of Technology.(in Indonesian).

Ying, Z. (2004). Structural Studies on Nucleocapsid Proteins of Shrimp White Spot Syndrome Virus. Thesis Submitted for The Degree of Master of Science, Department of Biological Sciences National University of Singapore.

Zhang, X., Huang, C., \& Qin, Q. (2004). Antiviral properties of hemocyanin isolated from shrimp Penaeus monodon. Antiviral Research, 61, 93-99. 